\title{
Two methods for isolation of endophytic and edaphic Bacillus spp. from sugarcane fields
}

\section{Dois métodos para isolamento de Bacillus spp. endofíticos e edáficos de canaviais}

\author{
Maria Elízia Pacheco Ferreira1 *, Luís Garrigós Leite', Ricardo Antônio Polanczyk², Marise Tanaka Suzuki³, \\ Raquel de Paula Freitas ${ }^{4}$, Roselaine Nunes da Silva Bueno', Raphael Satochi Abe da Silva'
}

\begin{abstract}
Bacillus has been widely studied and used for the control of pests and diseases. The adapted protocol proposed by POLANCZYK (2004) proved to be more efficient than the one by the World Health Organization (WHO, 1985) to isolate edaphic strains of Bacillus. However, it has not been assessed for isolation of endophytic strains, which are much less abundant in the nature and more difficult to be isolated. This study aimed to compare two methodological procedures for isolation of Bacillus, established by the WHO (1985) and by POLANCZYK (2004), regarding their efficiency for isolation of endophytics and edaphics Bacillus strains from inside the root tissue of sugarcane, as well as from the associated soil sample, collected from 11 locations; and to compare the density of bacteria in both environments. Endophytic and edaphic strains of Bacillus were isolated by both procedures. However, the isolation protocol performed by POLANCZYK (2004) made more efficient by having a greater number of colony forming units (CFU) per gram of soil and root indicating that this procedure is more useful, especially for isolation of endophytic strains of Bacillus, which are much less abundant in the nature than edaphic strains, being therefore more difficult to be isolated. Using the Polanczyk protocol (2004), Bacillus strains were recovered from all roots (endophytic) and soil (edaphic) samples of all the 11 fields, suggesting that the plant root may be another important source for isolation of Bacillus besides the soil. Higher densities of Bacillus were isolated from the edaphic environment compared with the endophytic environment, with significant differences when isolated by Polanczyk method (2004).
\end{abstract}

KEYWORDS: biological control; beneficial bacteria; soil; root; endospore.
RESUMO: Bacillus tem sido amplamente estudado e usado para o controle de pragas e doenças. O protocolo adaptado proposto por POLANCZYK (2004) mostrou-se mais eficiente do que o da Organização Mundial de Saúde (WHO, 1985) para isolar cepas edáficas de Bacillus. No entanto, não foi avaliado quanto ao isolamento de estirpes endofíticas, que são muito menos abundantes na natureza e mais difíceis de isolar. Este estudo teve como objetivos comparar dois procedimentos metodológicos para o isolamento de Bacillus, o estabelecido pela OMS (WHO, 1985) e o de POLANCZYK (2004), quanto a sua eficiência para o isolamento de estirpes endofitas e edáficas de Bacillus originárias do interior do tecido radicular de cana-de-açúcar, bem como de amostras de solos associados, coletada de 11 locais; e comparar a densidade de bactérias em ambos os ambientes. As cepas endofíticas e edáficas de Bacillus foram isoladas por ambos os procedimentos. No entanto, o protocolo de isolamento realizado por POLANCZYK (2004) demonstrou-se mais eficiente por gerar maior número de unidades de formação de colônias (CFU) por grama de solo e raiz, indicando que esse procedimento é mais útil, especialmente para isolamento de estirpes endofíticas de Bacillus, que são muito menos abundantes na natureza do que as cepas edáficas, sendo, portanto, mais difíceis de serem isoladas. Usando o protocolo de POLANCZYK (2004), as cepas de Bacillus foram isoladas de todas as amostras de raízes (endofíticas) e de solo (edáficas) de todos os 11 campos, sugerindo que a raiz da planta pode ser outra fonte importante de isolamento de Bacillus além do solo. As densidades mais altas de Bacillus foram isoladas do ambiente edáfico em comparação com o ambiente endofítico, com diferenças significativas quando isoladas pelo método de POLANCZYK (2004).

PALAVRAS-CHAVE: controle biológico; bactéria benéfica; solo; raiz; endósporos.

'Centro Experimental, Instituto Biológico - Campinas (SP), Brazil.

${ }^{2}$ Faculdade de Ciências Agrarias e Veterinárias, Universidade Estadual Paulista "Júlio de Mesquita Filho" - Jaboticabal (SP), Brazil.

${ }^{3}$ Centro Universitario de Gurupi (UnirG) - Gurupi (TO), Brazil.

${ }^{4}$ Centro de Solos e Recursos Agroambientais, Instituto Agronômico de Campinas (IAC) - Campinas (SP), Brazil.

*Corresponding author: marilifes@yahoo.com.br

Received on: 05/02/2016. Accepted on: 10/11/2017 


\section{INTRODUCTION}

Sugarcane (Saccharum officinarum L.), one the most important crops to Brazilian economy, is hampered by a number of sanitary problems, mainly by soil pests. The underground environment hosts the soil pests, but, on the other hand, it is also important reservoir of entomopathogens with potential for use in controlling these pests. These entomopathogens can be found in the soil (edaphic), on the surface of roots (rhizospheric) and inside the plant tissue (endophytic), including bacteria of the genus Bacillus, that has been studied and used for the control of pests and diseases, considered quite safe for the environment and non-target organisms.

Some Bacillus species such as Bacillus thuringiensis Berliner (Bt) and Bacillus sphaericus Neide (currently named Lysinibacillus sphaericus) produce crystal proteins, or parasporal bodies, which are rich in entomopathogenic endotoxins. These endotoxins are encoded by cry genes located both on the chromosomal and large plasmid DNAs with broad range spectrum against insects pests (BRAVO et al., 2011; GONZÁLES et al. 1982; SANCHIS et al., 1988; VAN FRANKENHUYZEN, 2009; 2013).

The aerobic endospore-forming bacteria Bacillus spp. has been widely isolated from soil samples (DANTAS et al., 2009; WHIPPS, 2001) and studied for promoting crop health, suppressing plant pathogens and pests, producing antibiotic metabolities, or stimulating plant host defenses prior to infection (GARDENER, 2004). While native populations of Bacillus occur abundantly in most agriculture soils, plant tissues are differently colonized by distinct subpopulations (GARDENER, 2004). For example, MONNERAT et al. (2009) assessed Bacillus thuringiensis Berliner $(B t)$ that were isolated also from the inner tissue of the plant (endophytic bacteria), demonstrating that this agents can be absorbed by the root system, reach other part of the plant by systemic circulation and kill insects feeding on the leaves.
Several protocols have been proposed for the isolation of bacteria of the genus Bacillus (JOHNSON; BISHOP, 1996; TRAVERS et al. 1987), including the commonly used protocol developed by the World Health Organization (WHO, 1985). A modification of the WHO (1985) protocol was proposed by POLANCZYK (2004), who suggested the following two isolation steps: 1) bacterial growth on solid medium; 2) bacterial sporulation in liquid medium supplemented with antibiotics, under agitation for 48-72 h. POLANCZYK (2004) protocol proved to be more efficient to isolate edaphic strains of Bacillus. However, it has not been assessed for isolation of endophytic strains, which are more difficult to be isolated and much less abundant in the nature than edaphic strains. Furthermore, no information has been provided concerning the natural incidence of endophytic and edaphic strains of Bacillus associated with the root tissue of sugarcane and related soil sample, in sugarcane fields.

For these reasons, the current study aimed to compare two methodological procedures established by the WHO (1985) and by POLANCZYK (2004), regarding their efficiency for isolation of Bacillus strains from inside the root tissue of sugarcane plants (endophytes), as well as from the associated soil sample (edaphic), and to compare the density of bacteria in both environments.

\section{MATERIALS AND METHODS}

Samples of sugarcane roots and of their associated soils were obtained on August 2010, from 11 fields of sugarcane with at least one ratoon crop (number of regrowth), located in nine cities of the state of Sáo Paulo (Table 1). All the plants belonged to the variety RB 96-7515, except for Campinas municipally, in which plants belonged to the variety CTC 7.

Table 1. Fields, cities, geographical coordinates and varieties of 11 fields of sugarcane, in nine municipalities of São Paulo state, where samples were taken to isolate Bacillus strains.

\begin{tabular}{|c|c|c|c|}
\hline Fields & Municipalities & Geographical coordinates & Variety \\
\hline 01 & Santo Antônio de Posse & S 22०37'10.1"/W 046॰58'04.8" & RB 96-7515 \\
\hline 02 & Santo Antônio de Posse & S 22037'01.6”/W 04658'51.0" & RB 96-7515 \\
\hline 03 & Holambra & S 22037'14.7"/W 046॰58'51.0" & RB 96-7515 \\
\hline 04 & Limeira & S 22॰32'49.6"/W 04720'30.5" & RB 96-7515 \\
\hline 05 & Araras & S 22०23'11.7"/W 047016'17.3" & RB 96-7515 \\
\hline 06 & Ipeúva & S 22०27'55.0”/W 04743'40.1" & RB 96-7515 \\
\hline 07 & Charqueada & S 22०28'06.5"/W 047०47’21.4" & RB 96-7515 \\
\hline 08 & São Pedro & S 22॰33’22.1"/W 04758'48.6" & RB 96-7515 \\
\hline 09 & São Pedro & S 22०34'00.7"/W 047॰58'04.0" & RB 96-7515 \\
\hline 10 & Santa Maria da Serra & 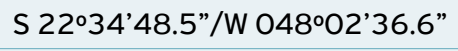 & RB 96-7515 \\
\hline 11 & Campinas & S 22०54'30.8"/W 047॰01'03.2" & СТС 7 \\
\hline
\end{tabular}


For each field, three plants located $5 \mathrm{~m}$ apart each other were up rooted, and the root systems were separated. Each root system and its associated soil were bagged, hold inside a polystyrene box and taken to the laboratory. Subsequently, the samples were prepared for isolation of Bacillus by two different methods proposed by WHO (1985) and POLANCZYK (2004).

\section{Samples preparation}

\section{Root}

Root samples were washed in running water using a sponge and soap to remove larger debris and then surface disinfested to eliminate the epiphytic microbial community as described by ARAÚJO et al. (2002).

The surface disinfestation was conducted inside a laminar flow hood and consisted of the following serial immersions of the plant material: $70 \%$ alcohol, 2 min; $3 \%$ sodium hypochlorite, $10 \mathrm{~min}$; 70\% alcohol, $1 \mathrm{~min}$; and sterile distilled water (twice consecutively), $30 \mathrm{~s}$.

To ensure surface disinfestation, $100 \mu \mathrm{L}$ samples of water obtained from the last wash were plated in triplicate onto a Petri dish containing Nutrient Agar (NA; $0.3 \%$ beef extract, $0.5 \%$ peptone, $0.8 \% \mathrm{NaCl}$, and $1.8 \%$ bacteriological agar). Then, the plates were covered and placed in an incubator chamber at $29^{\circ} \mathrm{C}$ for five days. After this period, the number of resulting colonies was determined.

Following the disinfestation procedure, 10 grams (g) of each root sample was immersed in a beaker containing 100 $\mathrm{mL}$ of saline solution $(0.8 \% \mathrm{NaCl})$, and then a mixer was used to grind these samples. The resulting extracts were used for isolation of Bacillus by the two methods, suggested by WHO (1985) and by POLANCZYK (2004).

\section{Soil}

Soil samples were prepared as following for isolation of Bacillus by the two methods. For each soil sample, $1 \mathrm{~g}$ was homogenized in $100 \mathrm{~mL}$ Erlenmeyer flasks containing $10 \mathrm{~mL}$ of saline solution $\left(0.006 \mathrm{mM} \mathrm{FeSO}_{4} 7 \mathrm{H}_{2} \mathrm{O} ; 0.01 \mathrm{mM} \mathrm{CaCO} 37 \mathrm{H}_{2} \mathrm{O} ; 0.08 \mathrm{mM}\right.$ $\mathrm{MgSO}_{4} 7 \mathrm{H}_{2} \mathrm{O} ; 0.07 \mathrm{mM} \mathrm{MnSO}_{4} 7 \mathrm{H}_{2} \mathrm{O} ; 0.006 \mathrm{mM} \mathrm{ZnSO}_{4}$ $7 \mathrm{H}_{2} \mathrm{O} ; \mathrm{pH}$ 7.0), as suggested by POLANCZYK (2004). These suspensions were shaken at $200 \mathrm{rpm}$ for $2 \mathrm{~h}$ to release the Bacillus cells from the colloid fraction of the soil. After this period, the suspended soil was used for isolation of Bacillus by the WHO (1985) method, and two dilutions of the suspended soil, $10^{-3}$ and $10^{-4}$, were used for isolation by the POLANCZYK (2004) method.

\section{Isolation procedures}

\section{World Health Organization Protocol}

Root extracts and undiluted soil suspensions were heated at $80^{\circ} \mathrm{C}$ for $12 \mathrm{~min}$ to kill non-sporulating bacteria, as well as vegetative forms of sporulating bacteria, which allowed for the recovery of only heat-resistant spores. Aliquots $(100 \mu \mathrm{L})$ from each sample were then plated onto three Petri dish plates containing NA supplemented with penicillin G $(100 \mathrm{mg} / \mathrm{L})$ to select for the growth of $B t$ and Bacillus cereus (JUNG et al., 1998).

The plates were placed in an incubator chamber at $29^{\circ} \mathrm{C}$ for five days. After, the number of colonies was estimated by considering the typical morphological features of Bacillus (average colony diameter of approximately $0.5 \mathrm{~cm}$, irregular borders, opacity, and whitish color).

\section{Polanczyk Protocol}

Root extracts and diluted soil suspensions $\left(10^{-3}\right.$ and $\left.10^{-4}\right)$ were heated at $80^{\circ} \mathrm{C}$ for $12 \mathrm{~min}$. Aliquots $(100 \mu \mathrm{L})$ from each sample were then plated onto three Petri dishes containing NA growth medium. The plates were placed into an incubator chamber at $29^{\circ} \mathrm{C}$ for five days. After it, the number of colonies was determined using the same methodology as described before for the WHO (1985) procedure.

Unlike the WHO (1985) protocol, to select for the growth of $B t$ and $B$. cereus, the previously characterized and identified colonies were inoculated in casein-casein-yeast (CCY) broth liquid growth medium (STEWART et al., 1981) supplemented with penicillin $\mathrm{G}(100 \mathrm{mg} / \mathrm{L})$ and placed under agitation at $200 \mathrm{rpm}$. A wire loop was used to inoculate each colony into tubes containing $5 \mathrm{~mL}$ of liquid medium, which were then kept under agitation (200 rpm) at $28^{\circ} \mathrm{C}$ for $72 \mathrm{~h}$. According to POLANCZYK (2004), the increased aeration rates that result from growing the bacteria in liquid medium under agitation optimizes not only the sporulation process, but also the production of crystal proteins (typical of $B t$ strains).

CCY broth supplemented with penicillin $\mathrm{G}(100 \mathrm{mg} / \mathrm{L})$ was used as the selective medium for growth and sporulation, because it is rich in metallic ions, including magnesium, iron, zinc, calcium, and manganese. These ions are responsible for the production of spores and for spore resistance to heat and ultraviolet (UV) radiation (BERNHARD; UTZ, 1993; LACEY, 1984). Furthermore, CCY broth components are rich in organic carbon, which plays an important role in the synthesis of crystals.

All of the colonies that grew in CCY broth with penicillin $\mathrm{G}(100 \mathrm{mg} / \mathrm{L})$, which caused this liquid medium to become turbid, were confirmed as members of the genus Bacillus based on their resistance to heat treatment and to penicillin $G$ at the given concentration.

\section{Identification and preservation}

All the colonies were observe in a microscope (Leica DM 2500) using $100 \mathrm{X}$ objective and identified as belonging to the genus Bacillus by the presence of spores. Subsequently, the colonies were preserved in sterile filter paper strips $(5 \mathrm{~cm} \times 0.5$ $\mathrm{cm}$ ), as suggested in the method adapted by MONNERAT; 
PRAÇA (2006). The cultures that grew in the CCY broth for $72 \mathrm{~h}$ were first subjected to heat treatment at $55^{\circ} \mathrm{C}$ for $40 \mathrm{~min}$ followed by placing $100 \mu \mathrm{L}$ samples of these cultures onto sterile filter paper strips, which were placed inside screw-cap tubes. Finally, the strips contained in the screw-cap tubes were dried in an incubator at $37^{\circ} \mathrm{C}$.

\section{Statistical analyses}

Colonies of Bacillus grown in each plate were transformed in colony forming unit (CFU), as well as in percentage of Bacillus from total colonies of bacteria, obtained per gram of sugarcane root and of its associated soil. Average of CFU/g (colony forming unit per gram) of root or soil, and average of percentage of Bacillus, obtained for the three plates (of each plant), were considered as a replication for a total of three replications (three plants of each field). Data were converted into Log (x +1) for counts and into Arco Seno $\sqrt{ } \mathrm{x} / 100$ for percentages, and subjected to Analysis of Variance using Statistical Package for the Social Sciences (SPSS) 10.0 statistics pack. Tukey's test was used to compare the averages $(\mathrm{p}<0.05)$. Correlation between edaphic and endophitic CFU counting was analyzed by Pearson correlation.

\section{RESULTS AND DISCUSSION}

Endophytic and edaphic strains of Bacillus were successfully isolated using the protocols developed by the $\mathrm{WHO}$ (1985) and by POLANCZYK (2004). The initial surface disinfestation procedure performed for the sugarcane root samples (prior to the isolation of the endophytic strains) yielded counts ranging from zero to four colonies of bacteria per Petri dishes plated with $100 \mu \mathrm{I}$ of the washed water, level acceptable per AZEVEDO et al. (2002).

Bacillus strains were recovered from all roots (endophytic) and soil (edaphic) samples of all the 11 fields, using the protocol developed by POLANCZYK (2004) (Table 2). Thus, plant root may be another important source for isolating Bacillus besides the soil. Using the WHO (1985) protocol, Bacillus colonies were isolated from root and soil samples of only three and five fields, respectively (Table 2).

Moreover, the protocol by POLANCZYK (2004) yielded significantly higher CFU counts of Bacillus per gram of soil $\left(5.64 \times 10^{2} \mathrm{CFU} / \mathrm{g}\right)$ and root $\left(1.7 \times 10^{2} \mathrm{CFU} / \mathrm{g}\right)$ than the WHO (1985) method $\left(0.18 \times 10^{2} \mathrm{CFU} / \mathrm{g}\right.$ of soil and $0.03 \times$ $10^{2} \mathrm{CFU} / \mathrm{g}$ of root) $(\mathrm{F}=392.9 ; \mathrm{d}=340 ; \mathrm{p}<0.001)$ (Table 2). These differences suggest that the penicillin added to the solid medium of the WHO (1985) procedure inhibit much more

Table 2. Colony counts of Bacillus ( $\times 10^{2}$ ) per gram of sugarcane root and of its associated soil, obtained from 11 fields of sugarcane, in nine municipalities of São Paulo state, isolated using two different methods.

\begin{tabular}{|c|c|c|c|c|c|}
\hline \multirow[b]{2}{*}{ Field } & \multirow[b]{2}{*}{ Municipally } & \multicolumn{2}{|c|}{ WHO (1985) } & \multicolumn{2}{|c|}{ Polanczyk (2004) } \\
\hline & & $\begin{array}{l}\text { CFU/g } \\
\text { of root }\end{array}$ & $\begin{array}{l}\text { CFU/g } \\
\text { of soil }\end{array}$ & $\begin{array}{l}\text { CFU/g } \\
\text { of root }\end{array}$ & $\begin{array}{l}\text { CFU/g } \\
\text { of soil }\end{array}$ \\
\hline \multirow{2}{*}{01} & \multirow{2}{*}{ Santo Antônio de Posse } & 0 & 0 & $1.8 \pm 0.1$ & $4,333.3 \pm 1,333.3$ \\
\hline & & a & a & $b$ & bcde \\
\hline \multirow{2}{*}{02} & \multirow{2}{*}{ Santo Antônio de Posse } & 0 & $0.1 \pm 0$ & $2.6 \pm 0.08$ & $6,000.0 \pm 577.3$ \\
\hline & & $a$ & a & & \\
\hline \multirow{2}{*}{03} & \multirow{2}{*}{ Holambra } & 0 & 0 & $3,4 \pm 0.4$ & $2,333.3 \pm 666.6$ \\
\hline & & $a$ & $a$ & $b$ & $a b c$ \\
\hline \multirow{2}{*}{04} & \multirow{2}{*}{ Limeira } & 0 & $1.8 \pm 0.2$ & $0.2 \pm 0.2$ & $500.0 \pm 0$ \\
\hline & & $a$ & $b$ & $\mathrm{a}$ & $\mathrm{a}$ \\
\hline \multirow{2}{*}{05} & \multirow{2}{*}{ Araras } & $0.03 \pm 0.03$ & $0.03 \pm 0.03$ & $0.1 \pm 0.03$ & $8,666.6 \pm 2,728.4$ \\
\hline & & a & $\mathrm{a}$ & a & $\mathrm{e}$ \\
\hline \multirow{2}{*}{06} & \multirow{2}{*}{ Ipeuna } & $0.2 \pm 0.2$ & 0 & $0.6 \pm 0.1$ & $1,000.0 \pm 173.2$ \\
\hline & & $a$ & a & $a b$ & $a b$ \\
\hline \multirow{2}{*}{07} & \multirow{2}{*}{ Charqueada } & 0 & 0 & $2,7 \pm 0.1$ & $5,000.0 \pm 577.4$ \\
\hline & & $a$ & $a$ & $b$ & cde \\
\hline \multirow{2}{*}{08} & \multirow{2}{*}{ São Pedro } & 0 & $0.3 \pm 0.03$ & $2.7 \pm 0.7$ & $25,333.3 \pm 333.3$ \\
\hline & & $a$ & $\mathrm{a}$ & $\mathrm{b}$ & $\mathrm{f}$ \\
\hline \multirow{2}{*}{09} & \multirow{2}{*}{ São Pedro } & 0 & 0 & $1.6 \pm 0.3$ & $1,100.0 \pm 100.0$ \\
\hline & & $\mathrm{a}$ & a & $b$ & $a b$ \\
\hline \multirow{2}{*}{10} & \multirow{2}{*}{ Santa Maria da Serra } & 0 & $1.0 \pm 0.1$ & $0.7 \pm 0.2$ & $1,400.0 \pm 264.6$ \\
\hline & & $a$ & $a$ & $a b$ & $a b c$ \\
\hline \multirow{2}{*}{11} & \multirow{2}{*}{ Campinas } & $0.1 \pm 0.06$ & 0 & $1.9 \pm 0.4$ & $6,333.3 \pm 1,855.9$ \\
\hline & & a & a & b & de \\
\hline \multirow{2}{*}{\multicolumn{2}{|c|}{ Total average }} & $0.03 \pm 0.02$ & $0.29 \pm 0.16$ & $1.7 \pm 0.3$ & $5,636.3 \pm 2,126$ \\
\hline & & a & a & b & c \\
\hline
\end{tabular}

Means with the same letter in column for data, and in row for total average, are not significantly different by Tukey's test at the 5\% significance level; CFU: colony forming units. 
Bacillus cells than when added to the liquid media of the POLANCZYK (2004) method. POLANCZYK (2004) highlighted the importance of using liquid medium with penicillin under aeration (agitation) to isolate $B t$ and $B$. cereus, because this procedure prevents the growth of antibiotic-sensitive bacteria and encourages sporulation due to the increased aeration.

However, the WHO (1985) protocol was slightly more specific for the isolation of Bacillus, with 100\% of the strains isolated from the roots and soil belonging to this genus. For the POLANCZYK (2004) method, 81 and 91\% of the bacteria isolated from the roots and soil were identified as Bacillus, respectively (Table 3). Meanwhile, these differences between the two procedures were not significant $(\mathrm{F}=2.53 ; \mathrm{d}=324 ; \mathrm{p}=0.081$ ) when the averages of the 11 fields were considered as replications for each environment in each methodology (Table 3).

The WHO (1985) protocol is the most widely used procedure to isolate bacteria of the genus Bacillus, because it is simple, fast, cost-effective, and simply involves inoculating heat-treated samples onto solid growth medium containing antibiotic. In contrast to the WHO (1985) procedure, the protocol developed by POLANCZYK (2004) consists of two isolation steps: 1) plating heat-treated samples onto solid growth medium without antibiotics; 2) bacterial growth and sporulation in liquid medium supplemented with the antibiotic penicillin $\mathrm{G}(100 \mathrm{mg} / \mathrm{L})$ under agitation for $48-72$ hours.
Polanczyk (2004) stated that its procedure is harder, longer, and more time-consuming than the WHO (1985) method. However, it is more efficient in the isolation of $B t$ and $B$. cereus.

Much higher densities of Bacillus were isolated from the edaphic environment compared with the endophytic environment (Table 2). As measured by the WHO (1985) method, the density of the edaphic strains $\left(0.29 \times 10^{2} \mathrm{CFU} / \mathrm{g}\right.$ of soil $)$ was 9.7-fold higher than the density of the endophytic strains $(0.03 \times$ $10^{2} \mathrm{CFU} / \mathrm{g}$ of root), but did not differed significantly each other $(\mathrm{F}=392.9 ; \mathrm{d}=340 ; \mathrm{p}=0.556)$. By using the POLANCZYK (2004) method, the density of edaphic strains $\left(5,636.3 \times 10^{2}\right.$ $\mathrm{CFU} / \mathrm{g}$ of soil) was 3,315.4-fold higher than the density of the endophytic strains $\left(1.7 \times 10^{2} \mathrm{CFU} / \mathrm{g}\right.$ of root), differing significantly each other $(F=392.9 ; d=340 ; p<0.001)$. Several studies have identified the soil as the main reservoir of Bacillus (IBARRA et al., 2003; MOHAMED et al., 2007).

Great variability was observed in the density of Bacillus obtained from the edaphic and endophytic environments in relation to the field origin, as demonstrated by POLANCZYK (2004) method (Table 2). Thus, as consequence of this great variability, correlation between edaphic and endophytic CFU counts was not significant by Pearson correlation $(\mathrm{p}=0.332)$. Fierer; SCHIMEL; HOLDEN (2003) noted the different microbiological profiles found in soil and subsoil, whereas other studies have identified effects of agricultural practices, such as

Table 3. Percentage of Bacillus from total colonies of bacteria obtained per gram of sugarcane root and of its associated soil, from 11 fields of sugarcane, in nine municipalities of São Paulo state, isolated using two different methods.

\begin{tabular}{|c|c|c|c|c|c|}
\hline \multirow{2}{*}{ Field } & \multirow{2}{*}{ Municipalities } & \multicolumn{2}{|c|}{ WHO (1985) } & \multicolumn{2}{|c|}{ Polanczyk (2004) } \\
\hline & & Root & Soil & Root & Soil \\
\hline 01 & Santo Antônio de Posse & - & - & $\begin{array}{c}71.5 \pm 10.5 \\
a\end{array}$ & $\begin{array}{c}74.6 \pm 12.9 \\
a\end{array}$ \\
\hline 02 & Santo Antônio de Posse & - & $\begin{array}{c}100 \\
a\end{array}$ & $\begin{array}{c}50.5 \pm 18.9 \\
a\end{array}$ & $\begin{array}{c}89.6 \pm 5.2 \\
a\end{array}$ \\
\hline $\mathrm{O3}$ & Holambra & - & - & $\begin{array}{c}52.7 \pm 13.9 \\
a\end{array}$ & $\begin{array}{c}77.7 \pm 11.1 \\
a\end{array}$ \\
\hline 04 & Limeira & - & $\begin{array}{c}100 \\
a\end{array}$ & $\begin{array}{c}66.6 \pm 33.3 \\
a\end{array}$ & $\begin{array}{c}100 \\
a\end{array}$ \\
\hline 05 & Araras & $\begin{array}{c}100 \\
a\end{array}$ & $\begin{array}{c}100 \\
a\end{array}$ & $\begin{array}{c}100 \\
a\end{array}$ & $\begin{array}{c}100 \\
a\end{array}$ \\
\hline 06 & Ipeúna & $\begin{array}{c}100 \\
a\end{array}$ & - & $\begin{array}{c}100 \\
a\end{array}$ & $\begin{array}{c}100 \\
a\end{array}$ \\
\hline 07 & Charqueada & - & - & $\begin{array}{c}98.8 \pm 1.1 \\
a\end{array}$ & $\begin{array}{c}100 \\
a\end{array}$ \\
\hline ०8 & São Pedro & - & $\begin{array}{c}100 \\
a\end{array}$ & $\begin{array}{c}100 \\
a\end{array}$ & $\begin{array}{c}100 \\
a\end{array}$ \\
\hline 09 & São Pedro & - & - & $\begin{array}{c}97.6 \pm 2.3 \\
a\end{array}$ & $\begin{array}{c}100 \\
a\end{array}$ \\
\hline 10 & Santa Maria da Serra & - & $\begin{array}{c}100 \\
a\end{array}$ & $\begin{array}{c}100 \\
a\end{array}$ & $\begin{array}{c}100 \\
a\end{array}$ \\
\hline 11 & Campinas & $\begin{array}{c}100 \\
a\end{array}$ & - & $\begin{array}{c}54.3 \pm 13.9 \\
a\end{array}$ & $\begin{array}{c}63.3 \pm 20.2 \\
a\end{array}$ \\
\hline Total a & age & $\begin{array}{c}100 \\
a\end{array}$ & $\begin{array}{c}100 \\
a\end{array}$ & $\begin{array}{c}81.1 \pm 6.5 \\
a\end{array}$ & $\begin{array}{c}91.4 \pm 4.0 \\
a\end{array}$ \\
\hline
\end{tabular}

Means with the same letter in column for data, and in row for total average, are not significantly different by Tukey's test at the 5\% significance level. 
soil management, crop rotations, agrochemical application, and agricultural equipment use, which lead to changes in the physical, chemical, and biological properties of soil (DICK, 1992; LARKIN, 2003). These factors could explain the differences in the Bacillus concentration observed for samples collected from different fields. Notably, as shown by POLANCZYK et al. (2004) method (Table 2), the samples obtained from the field 3 (Holambra) displayed the highest CFU counts in the endophytic environment, and one of the lowest CFU counts in the edaphic environment. An opposite counts was observed for the samples collected in the field 5, Araras (with one of the highest bacterial concentration from the soil and the lowest bacterial concentration from the root). Thus, as consequence of this great variability, correlation between edaphic and endophitic CFU counts was not significant by Pearson correlation $(\mathrm{P}=0.332)$.

Therefore, Bacillus population densities do not follow the same trend in the two environments (soil and root). It is also possible to conclude that apart from the microorganism's capability of penetrating the plant tissue, its potential to multiply, disperse, and persist inside of a plant can have an important role in determining the presence of a low or high density of endophytic microorganisms.

Up to now, researches on biodiversity in agro-ecosystems and the delivery of ecosystem services to agricultural production have usually ignored the contribution of entomopathogens in the regulation of pest populations. Knowledge of the ecology of indigenous populations of entomopathogens in agroecosystems, as well as the effects of environmental conditions and agricultural practices, is therefore necessary if they are to be manipulated for conservative biological control (MEYLING; EILENBERG, 2007). TSCHARNTKE et al. (2005) showed that the structure of the agricultural landscape has impact on agroecosystem biodiversity and thus the ecosystem services they deliver.
Annually cropped agroecosystems are highly disturbed mostly due to tillage regimes and it affects the populations of natural enemies of crop pests. The communities of entomopathogenic fungi, for example, in the arable soil environments are different from communities of less disturbed habitats (STEENBERG, 1995; BIDOCHKA et al., 1998; MEYLING; EILENBERG, 2006), and less disturbance in the cropping system also affect the populations of the fungi. For instance, no-till cultivation in soybean and wheat positively affected the population levels of Beauveria bassiana and Metarhizium anisopliae compared to conventional tillage (SOSA-GOMEZ; MOSCARDI, 1994).

\section{CONCLUSION}

In conclusion, both procedures established by the WHO (1985) and by POLANCZYK (2004) allow the isolation of endophytic and edaphic strains of Bacillus. The procedure developed by POLANCZYK (2004) yielded higher bacterial densities than the WHO (1985) procedure, which indicates that the POLANCZYK (2004) method is more useful, especially for isolation of endophytic strains of Bacillus, which is much less abundant in the nature than edaphic strains, being therefore more difficult to be isolated.

\section{ACKNOWLEDGEMENTS}

To the corporations Abengoa Bioenergy, Raizen and São João, for providing the cane and soil samples.

\section{REFERENCES}

ARAÚJO, W.L.; LIMA, A.O.S.; AZEVEDO, J.L.; MARCON, J.; KUKLINSKY-SOBRAL, J.; LACAVA, P.T. Manual: isolation of endophytes. Piracicaba: CALQ, 2002. 86p.

AZEVEDO, J.L.; MACCHERONI, W.J.; ARAÚJO, W.L.; PEREIRA, J.O. Endophytes and their role in tropical plants. In: SERAFINI, L.A.; BARROS, N. M.; AZEVEDO, J.L. (Eds). Biotechnology: Advances in Agriculture and Agribusiness. Caxias do Sul: Educs, 2002. p.233-268.

BERNHARD, K.; UTZ, R. Production of Bacillus thuringiensis Insecticides for Experimental and Commercial Uses. In: ENTERWISTLE, P.F.; CORY, J.S.; BAILEY, M.J.; HIGGS, S. (Eds.). Bacillus thuringiensis, an environmental biopesticide: Theory and Practice. Chichester: John Wiley and Sons, 1993. p.255-257.

BIDOCHKA, M.J.; KASPERSKI, J.E.; WILD, G.A.M. Occurrence of the entomopathogenic fungi Metarhizium anisopliae and Beauveria bassiana in soils from temperate and near- northern habitats. Canadian Journal of Botany, n.76, p.1 198-1204, 1998.

BRAVO, A.; LIKITVIVATANAVONG, S.; GILL, S.; SOBERÓN, M. Bacillus thuringiensis: a story of a successful bioinsecticide. Insect Biochemistry and Molecular Biology, v.41, p.423-431, 2011.

DANTAS, J.S.; SOUZA, A.P.; FARIAS, M.F.; NOGUEIRA, V.F.B. Interactions among groups of microorganisms with rhizosphere. Applied Research $\odot$ Agrotechnology, v.2, n.2, p.219-224, 2009. Available from: <http:// revistas.unicentro.br/index.php/repaa/article/view/113/1127>. Accessed on: Oct. 9, 2013. doi: 10.5777/paet.v2i2.113

DICK, R.P. A review: long-term effects of agricultural systems on soil biochemical and microbial parameters. Agriculture Ecosystems and Environment, v.40, n.1-4, p.25-36, 1992. Available from: <http:// www.sciencedirect.com/science/article/pii/016788099290081L >. Accessed on: Sept. 20, 2013. doi: 10.1016/0167-8809(92)90081-L 
FIERER, N.; SCHIMEL, J.; HOLDEN, P. Variations in microbial community composition through two soil depth profiles. Soil Biology and Biochemistry, v.35, p.167-176, 2003. Available from: <http://www.sciencedirect.com/science/article/pii/ S0038071702002511>. Accessed on: Oct. 9, 2013.

GARDENER, B.B.M. Ecology of Bacillus and Paenibacillus spp. in Agricultural Systems. Phytopathology, v.94, n.11, p.12521258, 2004. Available from: <http://www.ncbi.nlm.nih.gov/ pubmed/18944463>. Accessed on: May 8, 2015. doi: 10.1094/ PHYTO.2004.94.11.1252

GONZÁLES, J.M.J.; BROWN, B.S.; CARLTON, B.C. Transfer of Bacillus thuringiensis and Bacillus cereus. Proceedings of the National Academy of Sciences, v.79, n.22, p.6951-6955, 1982.

IBARRA, J.; RINCÓN, C.; ORDÚZ, S.; NORIEGA, D.; BENINTENDE, G.; MONNERAT, R.; REGIS, L; OLIVEIRA, C.M.F.; LANZ,H.; RODRIGUEZ, M.H.; SÁNCHEZ, J.; PEÑA, G.; BRAVO, A. Diversity of Bacillus thuringiensis strains from Latin America with insecticidal activity against different mosquito species. Applied and Environmental Microbiology, v.69, n.9, p.5269-5274, 2003. Available from: <http://www.ncbi.nlm. nih.gov/pmc/articles/PMC 194983/pdf/0635.pdf>. Accessed on: Oct. 9, 2013. doi: 10.1 128/AEM.69.9.5269-5274.2003

JOHNSON, C.; BISHOP, A.H. A technique for the effective enrichment and isolation of Bacillus thuringiensis. FEMS Microbiology Letters, v.142, p.173-177, 1996. Available from: <http://www.sciencedirect.com/science/article/ pii/0378109796002613>. Accessed on: Oct 9, 2013. doi: 10.1016/0378-1097(96)00261-3

JUNG, Y.C.; KIM, S.U.; CÔTÉ, J.C.; LECADET, M.M.; CHUNG, Y.S.; BOK, S.H. Characterization of a new Bacillus thuringiensis subsp. Higo strain isolated from rice bran in Korea. Journal of Invertebrate Pathology, v.7 1, n. 1, p.95-96, 1998. Available from: <http://www. sciencedirect.com/science/article/pii/SOO22201197946978>. Accessed on: Oct. 09, 2013. doi: 10.1006/jipa.1997.4697

LACEY, L.A. Production and formulation of Bacillus sphaericus. Mosquito News, v.44, p.153-159, 1984.

LARKIN, R.P. Characterization of soil microbial communities under different potato cropping systems by microbial population dynamics, substrate utilization, and fatty acid profiles. Soil Biology and Biochemistry, v.35, n. 11 , p.1451-1466, 2003. Available from: <http://www. sciencedirect.com/science/article/pii/S0038071703002402>. Accessed on: Oct. 9, 2013. doi: 10.1016/SOO38-0717(03)00240-2

MEYLING, N.V.; EILENBERG, J. Ecology of the entomopathogenic fungi Beauveria bassiana and Metarhizium anisopliae in temperate agroecosystems: Potential for conservation biological control. Biological Control, v.43, p. 145-155, 2007.

MEYLING, N.V.; EILENBERG, J. Occurrence and distribution of soil borne entomopathogenic fungi within a single organic agroecosystem. Agriculture, Ecosystems and Environment, v. 1 13, p.336-341, 2006.

MOHAMED, E.A.H.; ABE, M.; GHANEM, K.M.; ABDEL-FATTAH, Y.R.; NAKAGAWA, Y.; EL-HELOW, E.R. Diversity of Bacillus Genotypes in soil samples from El-omayed biosphere reserve in Egypt. Journal of Culture Collections, v.5, p.78-84, 2007. Available from: <http://www.nbimcc.org/JCC/2007/JCCO7511/JCCO7511. pdf>. Accessed on: Oct. 9, 2013.
MONNERAT, R.G.; PRAÇA, L.B. Bacillus thuringiensis and Bacillus sphaericus. In: OLIVEIRA-FILHO, E.C.; MONNERAT, R.G. (Eds.). Rationale for regulation semiochemicals, natural enemies and microbiological agents of pest control. Planaltina: Embrapa Cerrado, 2006. p.121-155.

MONNERAT, R.G.; SOARES, C.M.; CAPDEVILLE, G.; JONES, G.; MARTINS, É.S.; PRAÇA, L.; CORDEIRO, B.A.; BRAZ, S.V.; SANTOS, R.C.; BERRY, C. Translocation and insecticidal activity of Bacillus thuringiensis living inside of plants. Microbial Biotechnology, v.2, n.4, p.512-520, 2009. Available from: <http://onlinelibrary.wiley. com/doi/10.1111/j.1751-7915.2009.00116.x/pdf >. Accessed on: Sept. 23, 2013. doi: 10.1111/j.1751-7915.2009.00116.x

POLANCZYK, R.A. Estudos de Bacillus thuringiensis Berliner visando ao controle de Spodoptera frugiperda (J. E. Smith). 144f. Thesis (Doutorado em Entomologia) - Escola Superior de Agricultura "Luiz de Queiroz”, Universidade de São Paulo, Piracicaba, 2004. Available from: <http://www.teses.usp.br/teses/disponiveis/11/11146/tde22092004-144726/pt-br.php>. Accessed on: Nov. 18, 2011.

SANCHIS, V.; LERECLUS, D.; MENOU, G.; CHAUFAUX, J.; LECADET, M.M. Multiplicity of $\S$-endotoxin genes with different insecticidal specificities in Bacillus thuringiensis aizawai 7.29. Molecular Microbiology, v.2, n.3, p.393-404, 1988.

SOSA-GOMEZ, D.R.; MOSCARDI, F. Effect of till and no-till soybean cultivation on dynamics of entomopathogenic fungi in the soil. Florida Entomologist, v.77, p.284-287, 1994.

STEENBERG, T. Natural occurrence of Beauveria bassiana (Bals.) Vuill. with focus on infectivity to Sitona species and other insects in lucerne. Thesis (Doutorado) - The Royal Veterinary and Agricultural University, Denmark, 1995.

STEWART, G.S.; JOHNSTONE, K.; HAGELBERG, E.; ELLAR, D.J. Commitment of bacterial spores to germinate. A measure of the trigger reaction. Biochemistry Journal, v.198, p.101106, 1981. Available from: <http://www.biochemj.org/ bj/198/0101/1980101.pdf>. Accessed on: Oct. 9, 2013.

TRAVERS, R.S.; MARTIN, P.A.W.; REICHELDERFER, C.F. Selective process for efficient isolation of soil Bacillus spp. Applied and Environmental Microbiology Journal, v.53, n.6, p.1263-1266, 1987. Available from: <http://www.ncbi.nlm.nih.gov/pmc/articles/PMC203852/ pdf/aem00123-0067.pdf >. Accessed on: Sept. 23, 2013.

TSCHARNTKE, T.; KLEIN, A.M.; KRUESS, A.; STEFFAN-DEWENTER, I.; THIES, C. Landscape perspectives on agricultural intensification and biodiversity - ecosystem service management. Ecology Letters, v.8, p.857-874, 2005.

VAN FRANKENHUYZEN, K. Cross-order and cross-phylum activity of Bacillus thuringiensis pesticidal proteins. Journal of Invertebrate Pathology, v.114, p.76-85, 2013.

. Insecticidal activity of Bacillus thuringiensis crystal proteins. Journal of Invertebrate Pathology, v.101, p. 1-16, 2009.

WHIPPS, J.M. Microbial interactions and biocontrol in the rhizosphere. Journal of Experimental Botany, v.52, p.487-51 1, 2001.

WORLD HEALTH ORGANIZATION (WHO). Informal consultation on the development of Bacillus sphaericus as a microbial larvicide. Geneva: WHO, 1985. 24p. 